Copyright (C) 2021 by Cherkas Global University

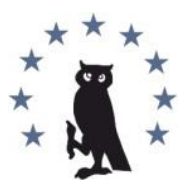

Published in the USA

Slavery: Theory and Practice

Has been issued since 2016.

E-ISSN: 2500-3755

2021. 6(1): 54-57

DOI: 10.13187/slave.2021.1.54

https://stp.cherkasgu.press

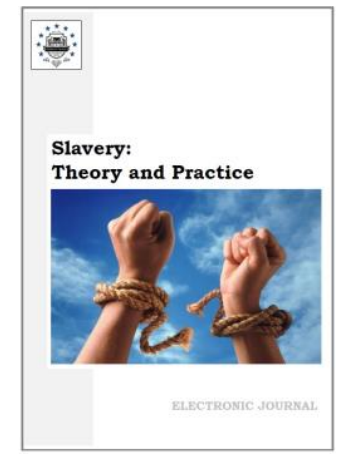

\title{
In Memory of Vladimir Alexandrovich Zakharov (o7.17.1946-01.11.2021)
}

\author{
Dmitry S. Dudarev a , * \\ ${ }^{a}$ LLC "Projects of the Capital", Russian Federation, Moscow, Rusian Federation
}

\section{Abstract}

The article is dedicated to the memory of V.A. Zakharov. The area of scientific interests of V.A. Zakharov was very broad. His research is devoted to the history of the Tmutarakan principality, "The Word of Igor's Regiment", the life of M.Yu. Lermontov, the ethno-political history of the Transcaucasian states, the North Caucasus, Abkhazia, Turkey, the history of Western Europe during the Middle Ages and modern times, especially the well-known Order of Malta. V.A. Zakharov is the author of over 1100 articles, 74 books. His articles were published in newspapers, magazines and scientific collections of Russia, Ukraine, Armenia, Bulgaria, Poland, Islamic Republic of Iran, Canada, USA. V.A. Zakharov was known as a public figure. He was a member of the Writers 'Union of Russia and the Writers' Union of Armenia, co-chairman of the Russian Lermontov Committee, a member of the International Union of Journalists.

Keywords: Tmutarakan principality, "Word about Igor's regiment", M.Yu. Lermontov, Russian Orthodox Church, Order of Malta.

1 ноября 2021 г. ушел из жизни видный отечественный историк, литературовед, политолог, деятель Русской православной церкви Владимир Александрович Захаров.

В.А. Захаров родился 17 июля 1946 г. в Армавире. Учился в железнодорожной средней школе № 49. Уже с юных лет Владимир Александрович оказался связанным с изучением истории родного города и края. Его путь в науку - пример для нынешних подрастающих поколений армавирцев и кубанцев. С третьего класса В. Захаров был «музейным мальчиком» при Армавирском городском музее. Вместе с известными местными краеведами Б.Л. Выродовым, Н.И. Навротским и приезжавшими в Армавир палеонтологами из Ленинграда (Е.Ф. Кутузкиной) и из Тбилиси (Л.К. Габуния) занимался археологическими и палеонтологическими раскопками в районе Форштадта. Вместе с Б.Л. Выродовым Захаров раскопал в районе «Чертова моста» в Форштадте скелет кита цетотерия (Cetotherium), который обитал на месте нынешнего города Армавира свыше 10 млн лет назад. Еще школьником В. Захаров вел активную переписку с писателем Р.Т. Пересветовым и главным хранителем отдела нумизматики государственного Эрмитажа И.Г. Спасским, по рекомендации которого начал заниматься научной темой «История денежных знаков города Армавира». Тогда же юноша стал заниматься в архиве г. Армавира (ныне Архивный отдел администрации МО Армавир). Дорога молодого человека прямиком лежала в науку.

И, казалось бы, так и было. С 1964 г. В. Захаров обучается на историкофилологическом факультете Ставропольского государственного педагогического института, где судьба свела его с видным историком, профессором В.А. Романовским, память которого

\footnotetext{
* Corresponding author

E-mail addresses: dudarev324@gmail.com (D.S. Dudarev)
} 
чтут ныне историки СКФУ, и стал его личным секретарем. Но не только с исторической и другими науками была связана жизненная стезя В.А. Захарова. Будучи из церковной семьи, он не утратил этой связи, за что и пострадал. В 1969 г. студента Захарова исключили из вуза за «принадлежность к лицам религиозного объединения». «Компетентные органы» инкриминировали молодому человеку то, что он был тайным иподиаконом архиепископа Ставропольского и Пятигорского Михаила (Чуба) (Священник Александр Гурин, 2021). Случившееся могло сильно поколебать жизненные устои многих, но не В.А. Захарова.

После исключения из института он с трудом устроился на работу рабочим сцены Ставропольского драматического театра, где вскоре стал главным машинистом, проработав 5 лет. Впоследствии Захаров уехал из Ставрополя в Кисловодск. Несколько раз Владимир Александрович встречался с А.И. Солженицыным в Москве в 1972-1973 гг., которому возил письма из Новопятигорска от его крестной матери М. Крамер (Скороглядовой), а от него привозил рукописи не опубликованных в СССР романов Солженицына. В те времена это было очень рискованным занятием, которое могло закончиться долгим тюремным или лагерным сроком. Завершать образование пришлось без отрыва от производства: в 1975 г. B.А. Захаров закончил Московский государственный заочный педагогический институт по специальности - историк.

Полем его плодотворной деятельности надолго стала музейная работа. Владимир Александрович трудился в музеях Пятигорска, Пензы (Тарханы), Краснодарского края (Тамань 1976-1986), Москвы. Он является одним из создателей Дома-музея М.Ю. Лермонтова в Тамани. Вместе с В.Г. Малаховой им был разработан тематикоэкспозиционный план нескольких литературных экспозиций. Проведенные Захаровым научные исследования в Краснодарском и Ставропольском госархивах (ГАКК и ГАСК), а также в Военно-историческом архиве (РГВИА), рукописных отделах Пушкинского дома (ИРЛИ) и библиотеки им В.И. Ленина (ныне РНБ) позволили ввести в историю Тамани и в лермонтоведение немало новых страниц. Там, на Тамани, рядом с родителями, В.А. Захаров ныне и похоронен...

Особой областью приложения усилий В.А. Захарова являлось церковное служение. С конца 1970-х гг. он занимался открытием православных храмов. Так, по его инициативе было возобновлено богослужение в храме Покрова (храм Василия Блаженного на Красной площади в Москве). В 1990-1991 гг. три месяца находился в Свято-Троицком монастыре Русской зарубежной церкви в Джорданвилле (США), преподавал историю России в Джорданвилльской семинарии. С 1993 г. В.А. Захаров работал в отделе по церковной благотворительности и социальному служению Московской патриархии.

В 1995 г. он был приглашен на работу канцлером в миссию Суверенного военного мальтийского ордена при РФ. С 2001 года являлся старшим научным сотрудником Института Европы РАН, с 2005 г. - заместителем директора «Центра Кавказских исследований» МГИМО(У) МИД России, с 2009 года - профессором Пятигорского государственного лингвистического университета. В течение ряда лет В.А. Захаров был президентом Института политических и социальных исследований ЧерноморскоКаспийского региона им. В.Б. Арцруни (г. Москва).

Область научных интересов В.А. Захарова была весьма широка. Его исследования посвящены истории Тмутараканского княжества, «Слову о полку Игореве», жизни М.Ю. Лермонтова, этнополитической истории закавказских государств, Северного Кавказа, Абхазии, Турции, истории Западной Европы периода Средневековья и Нового времени, особенно широко известного Мальтийского ордена. Особо нужно отметить то, что В.А. Захаров был одним из ведущих и старейших лермонтоведов России. Его многочисленные выступления на научных Всесоюзных и Всероссийских лермонтовских конференциях всегда привлекали внимание своей новизной материала, новыми архивными находками, а 7о0-страничная книга «Летопись жизни и творчества М.Ю. Лермонтова» стала настольной книгой всех, кто занимается изучением жизни и творчества великого русского поэта. Многочисленные выступления В.А. Захарова в прессе и на телевидении популяризировали творчество Лермонтова, раскрывая перед новым поколением неизвестные страницы творческой биографии поэта. Владимир Александрович был настоящим кладезем знаний из различных областей отечественной и зарубежной истории, 
в том числе о прошлом родного города, прекрасным лектором и рассказчиком. В последние годы он был членом редколлегии журнала «Slavery: Theory and Practice».

В.А. Захаров являлся автором более 1100 статей, 74 книг. Его статьи публиковались в газетах, журналах и научных сборниках России, Украины, Армении, Болгарии, Польши, Исламской республики Иран, Канады, США (Прохоров, 1995; Захаров Владимир Александрович, 2002; Владимир Александрович Захаров, 2004; После юбилея, 2015; Библиография..., 2016).

В.А. Захаров был известен как значимый общественный деятель. Он являлся членом Союза писателей России и Союза писателей Армении, сопредседателем Российского Лермонтовского комитета (со времени его создания в 2008 г. вместе с Расулом Гамзатовым и Владимиром Карповым), членом Международного союза журналистов.

Неутомимая и плодотворная научная и общественная работа В.А. Захарова снискала ему высокий и заслуженный авторитет и неоднократно поощрялась различными высокими почётными наградами и званиями, в том числе и высшими орденами: Св. Даниила Московского (РПЦ), Нестора Летописца 12-й степени (Украинская православная церковь Московского патриархата), Павла Первого (Русская зарубежная церковь - США), высшим орденом Суверенного военного мальтийского ордена (S.M.O.M) «Командорский крест» pro Merito Melitensi ${ }^{1}$, медалью 10о0-летия крещения Руси, медалью «За службу на Северном Кавказе» (2007 г.), медалью «Вачаган Барепашт» (Нагорно-Карабахская республика), Золотой медалью «Тюрксоя» (эта медаль вручалась всего дважды - Президенту Турции Абдулле Гюлю и В.А. Захарову) и др.

Память о Владимире Александровиче Захарове - большом ученом и незаурядном человеке, всецело преданном исторической науке, патриоте России и Армении - надолго сохранится среди нас.

\section{Литература}

Библиография..., 2016 - Библиография научных работ Владимира Александровича Захарова. К 7о-летию со дня рождения и 50-летию научной и общественной деятельности // Известия Научно-педагогической кавказоведческой школы В.Б. Виноградова. Вып. 4 (под ред. С.Л. Дударева). М.: Издательство Русская панорама. 2016. 112 с.

Владимир Александрович Захаров, 2004 - Владимир Александрович Захаров / Лермонтовский текст: Ставропольские исследователи о жизни и творчестве М.Ю. Лермонтова: Антология / Под ред. проф. В.А. Шаповалова, проф. К.Э. Штайн. Ставрополь: Изд-во СГУ, 2004. С. 580.

Захаров Владимир Александрович, 2002 - Захаров Владимир Александрович (1946 г.р.). Под ред. В.Б. Виноградова / Российские исследователи Кавказа. История, археология, этнография. Вып. 22. Из эпистолярного наследия. Вып. 6. Армавир; Москва, 2002. 28 с. [Список основных печатный работ В.А. Захарова. С. 16-27].

Прохоров, 1995 - Прохоров Г.М. Захаров Владимир Александрович / Энциклопедия «Слово о полку Игореве». Т. 2. СПб.: Дмитрий Буланин, 1995. С. 213-214.

После юбилея, 2015 - После юбилея. Владимир Захаров о Лермонтове, лермонтоведении, литературных мифах и исторической памяти. Ярославль. Центральная библиотека им. M.Ю. Лермонтова. 07.04.2015 16:00. [Электронный pecypc]. URL: http://www.clib.yar.ru/modules.php?name=News\&file=art icle\&sid=3042

Священник Александр Гурин, 2021 - Священник Александр Гурин. Взаимоотношения власти с Русской Православной церковью (1917-1990) // Человек в зоне. Вып. 21-1. Фонд Инок. 2021. $31 \mathrm{c.}$

\section{References}

Bibliografiya..., 2016 - Bibliografiya nauchnyh rabot Vladimira Aleksandrovicha Zaharova. K 70-letiyu so dnya rozhdeniya i 50-letiyu nauchnoj i obshchestvennoj deyatel'nosti [Bibliography of scientific works of Vladimir Alexandrovich Zakharov. To the 70th anniversary of the birth and the 5oth anniversary of scientific and social activities]. Izvestiya nauchno-pedagogicheskoj

\footnotetext{
${ }^{1}$ Чтобы читателю был понятен межгосударственный уровень этой награды, отметим, что другой такой орден в РФ имеет только министр обороны С.К. Шойгу (Ред.).
} 
Kavkazovedcheskoj Shkoly V.B. Vinogradova. Vyp.4 (pod red. S.L. Dudareva). M.: Izdatel'stvo Russkaya panorama. 2016. 112 p. [in Russian]

Posle yubileya, 2015 - Posle yubileya [After the anniversary]. Vladimir Zaharov o Lermontove, lermontovedenii, literaturnyh mifah i istoricheskoj pamyati. Yaroslavl'. Central'naya biblioteka im. M.Yu. Lermontova. 07.04.2015 16:00. [Electronic resource]. URL: http://www.clib.yar.ru/modules.php?name=News\&file=art icle\&sid=3042 [in Russian]

Prohorov, 1995 - Prohorov, G.M. (1995). Zaharov Vladimir Aleksandrovich. Enciklopediya «Slovo o polku Igoreve». T. 2. SPb.: Dmitrij Bulanin, pp. 213-214. [in Russian]

Svyashchennik Aleksandr Gurin, 2021 - Svyashchennik Aleksandr Gurin. Vzaimootnosheniya vlasti s Russkoj Pravoslavnoj cerkov'yu (1917-1990) [The relationship of power with the Russian Orthodox Church (1917-1990)]. Chelovek v zone. Vyp. 21-1. Fond Inok. 2021. 31 p. [in Russian]

Vladimir Aleksandrovich Zaharov, 2004 - Vladimir Aleksandrovich Zaharov. Lermontovskij tekst: Stavropol'skie issledovateli o zhizni i tvorchestve M.Yu. Lermontova: Antologiya. Pod red. prof. V.A. Shapovalova, prof. K.E. Shtajn. Stavropol': Izd-vo SGU, 2004. 580 p. [in Russian]

Zaharov Vladimir Aleksandrovich, 2002 - Zaharov Vladimir Aleksandrovich (1946 g.r.). Pod red. V.B. Vinogradova. Rossijskie issledovateli Kavkaza. Istoriya, arheologiya, etnografiya. Vyp. 22. Iz epistolyarnogo naslediya. Vyp. 6. Armavir; Moskva, 2002. 28 p. [Spisok osnovnyh pechatnyj rabot V.A. Zaharova. Pp. 16-27]. [in Russian]

\section{Памяти Владимира Александровича Захарова (17.07.1946-01.11.2021)}

Дмитрий Сергеевич Дударев ${ }^{\text {a , * }}$

a ООО «Проекты столицы», г. Москва, Российская Федерация

Аннотация. Статья посвящена памяти недавно ушедшего из жизни видного отечественного историка, литературоведа, политолога, деятеля Русской православной церкви В.А. Захарова. Область научных интересов В.А. Захарова была весьма широка. Его исследования посвящены истории Тмутараканского княжества, «Слову о полку Игореве», жизни М.Ю. Лермонтова, этнополитической истории закавказских государств, Северного Кавказа, Абхазии, Турции, истории Западной Европы периода Средневековья и Нового времени, особенно широко известного Мальтийского ордена. В.А. Захаров являлся автором более 1100 статей, 74 книг. Его статьи публиковались в газетах, журналах и научных сборниках России, Украины, Армении, Болгарии, Польши, Исламской республики Иран, Канады, США. В.А. Захаров был известен как общественный деятель. Он являлся членом Союза писателей России и Союза писателей Армении, сопредседателем Российского Лермонтовского комитета, членом Международного союза журналистов.

Ключевые слова: Тмутараканское княжество, «Слово о полку Игореве», М.Ю. Лермонтов, Русская православная церковь, Мальтийский орден.

\footnotetext{
* Корреспондирующий автор

Адреса электронной почты: dudarev324@gmail.com (Д.С. Дударев)
} 